\title{
Response of cabbage to nitrogen fertilization in the northeastern region of Pará State
}

\section{Resposta do repolho à fertilização nitrogenada na região nordeste do Estado do Pará}

\author{
Lívia Tálita da Silva CARVALHO'; Joaquim Alves de LIMA JUNIOR²; André Luiz Pereira da SILVA3; \\ Pedro Daniel de OLIVEIRA ${ }^{4}$; Gerson Diego Pamplona ALBUQUERQUE5; José Félix de BRITO NETO ${ }^{6}$
}

${ }^{1}$ Autor para correspondência; Estudante de Agronomia; Universidade Federal Rural da Amazônia - Campus de Capanema,
Rua João Pessoa, 121, Bairro Centro. Capanema-PA; liviatalita10@hotmail.com
2Doutor em Agronomia; Universidade Federal Rural da Amazônia; joaquim.junior@ufra.edu
${ }^{3}$ Doutor em Agronomia; Universidade Estadual Paulista; andreengagronomo@gmail.com
${ }^{4}$ Doutor em Agronomia; Universidade Federal Rural da Amazônia; daniel.oliveira@ufra.edu
${ }^{5}$ Doutorando em Agronomia; Universidade Federal Rural da Amazônia; gerson.albuquerque@ufra.edu.br
${ }^{6}$ Doutor em Agronomia; Universidade Estadual da Paraíba; jose.felix@ccaa.uepb.edu.br

Recebido em: 08-06-2017; Aceito em: 16-07-2018

\begin{abstract}
Low rates of $\mathrm{N}$ may result in low yield and small cabbage heads due to reduced leaf area. On the other hand, very high rates of $\mathrm{N}$ may favor excessive leaf growth, reducing sugar and vitamin $\mathrm{C}$ contents and head dry matter. This work evaluates the influence of $\mathrm{N}$ rates on the development and production of cabbage. The experiment was conducted under field conditions at the Experimental Farm of Igarapé Açu (FEIGA), in the municipality of Igarapé Açu. The soil of the region is classified as Dystrophic Yellow Argisol, with sandy texture. The experimental design was randomized blocks, with five treatments and three replications. The treatments evaluated were Nitrogen rates $\left(0 ; 90 ; 180 ; 270\right.$; and $\left.360 \mathrm{~kg} \mathrm{ha}^{-1}\right)$ in the form of urea, applied in top dressing. The $\mathrm{N}$ rate that maximized cabbage head production $(0.60 \mathrm{~kg})$ was $249.5 \mathrm{~kg} \mathrm{~N} \mathrm{ha}^{-1}$. The rate that maximized commercial yield $\left(16883.81 \mathrm{~kg} \mathrm{ha}^{-1}\right)$ was $270.27 \mathrm{~kg} \mathrm{~N} \mathrm{ha}^{-1}$.
\end{abstract}

Additional keywords: Brassica oleracea var. capitata L; fertilization; yield.

\section{Resumo}

Na cultura de repolho, menores doses de $\mathrm{N}$ podem resultar em baixa produtividade e em cabeças pequenas, por causa da reduzida área foliar. Por outro lado, doses muito altas de $\mathrm{N}$ podem favorecer o crescimento excessivo das folhas, reduzir os teores de açúcares e de vitamina $\mathrm{C}$ e a massa da matéria seca da cabeça. $\mathrm{O}$ objetivo deste trabalho foi avaliar a influência de doses de $\mathrm{N}$ no desenvolvimento e na produção do repolho. $\mathrm{O}$ experimento foi conduzido a campo na Fazenda Experimental de Igarapé-Açu (FEIGA), no município de IgarapéAçu. O solo da região foi classificado como Argissolo Amarelo distrófico, com textura arenosa. O delineamento experimental adotado foi em blocos casualizados, com cinco tratamentos e três repetições. Os tratamentos avaliados foram doses de nitrogênio $\left(0 ; 90 ; 180 ; 270\right.$ e $\left.360 \mathrm{~kg} \mathrm{ha}^{-1}\right)$ na forma de ureia, aplicadas em cobertura. As doses de $\mathrm{N}$ que maximizaram a produção de cabeças de repolho $(0,60 \mathrm{~kg})$ foram de $249,5 \mathrm{~kg} \mathrm{de} \mathrm{N} \mathrm{ha}^{-1}$, e da produtividade comercial $\left(16.883,81 \mathrm{~kg} \mathrm{ha}^{-1}\right)$, de $270,27 \mathrm{~kg}$ de $\mathrm{N} \mathrm{ha}^{-1}$.

Palavras-chave adicionais: adubação; Brassica oleracea var. capitata L; produtividade.

\section{Introduction}

Cabbage (Brassica oleracea var. capitata L.) is the species of major socioeconomic importance of the Brassicaceae family. It is one of the most efficient vegetables in food production, given its high growth rate and excellent nutraceutical value.

At the national level, cabbage has a great economic expression, and is characterized by short cycle time, shallow root system and high demand for nutrients, requiring high fertilizer rates to express its yield potential (Cecílio Filho et al., 2016). Over time, cultivars adapted to high temperatures were obtained, thus expanding the planting and harvest periods (Moreira et al., 2011).
Among the nutrients, nitrogen $(\mathrm{N})$ is responsible for the formation of chlorophyll and production of proteins and amino acids, which the plant needs for its growth and inflorescence development (May et al., 2007). In this sense, lower nitrogen rates can result in low yield and smaller heads, because of the decrease in leaf area (Cardoso \& Hiraki, 2001; Torres et al., 2003). On the other hand, very high rates of $N$ may favor excessive leaf growth, reducing sugar and vitamin C contents and head dry matter (Kano et al., 2007; Din et al., 2007).

The optimal management of fertilization in cabbage crop can be achieved by synchronizing the plant's demand with the $\mathrm{N}$ supply during the crop cycle (Moreira et al., 2011). Cabbage is a leafy vegetable 
and, as such, the $\mathrm{N}$ tends to be the nutrient of greater influence on yield and quality. This is because in addition to stimulating leaf growth, it is a component of amino acids and proteins (Aquino et al., 2009). The proper $\mathrm{N}$ fertilization is critical to nutritional balance, which, in turn, is responsible for plant growth and for the production of new cells and tissues.

In this context, this work evaluates the influence of nitrogen rates on cabbage development, aiming to determine the maximum $\mathrm{N}$ rate that provides maximum yield and productivity.

\section{Material and methods}

The experiment was conducted under field conditions at the Experimental Farm of Igarapé Açu (FEIGA), in the municipality of Igarapé Açu, situated at an altitude of $39 \mathrm{~m}$ and with the following geographic

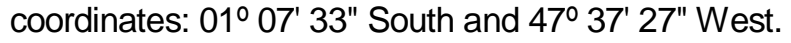

The soil of the region is classified as Dystrophic Yellow Argisol, with sandy texture (Embrapa, 2013). The results of the fertility and granulometry analysis of the experimental area, obtained from a soil sample collected at 0-0.2 m depth, were: $\mathrm{pH}_{\mathrm{H} 2 \mathrm{O}}=5.2 ; \mathrm{N}=0.06 \%$; organic matter $=$ $=13.76 \mathrm{~g} \mathrm{~kg}^{-1} ; \mathrm{P}=20 \mathrm{mg} \mathrm{dm}^{-3} ; \mathrm{Ca}=1.8 \mathrm{cmol}_{\mathrm{c}} \mathrm{dm}^{-3}$; $\mathrm{Mg}=0.5 \mathrm{cmol}_{\mathrm{c}} \mathrm{dm}^{-3} ; \mathrm{K}=0.013 \mathrm{cmol}_{\mathrm{c}} \mathrm{dm}^{-3} ; \mathrm{Na}=$ $=0.013 \mathrm{cmol}_{\mathrm{c}} \mathrm{dm}^{-3} ; \mathrm{SB}=2.33 \mathrm{cmol}_{\mathrm{c}} \mathrm{dm}^{-3} ; \mathrm{H}+\mathrm{Al}=$ $=2.48 \mathrm{cmol}_{\mathrm{c}} \mathrm{dm}^{-3} ; \mathrm{CEC}=4.81 ; \mathrm{V}: 48 \%$; $\mathrm{B}=0.52 \mathrm{mg} \mathrm{dm}^{-3} ; \mathrm{Cu}=2 \mathrm{mg} \mathrm{dm}^{-3} ; \mathrm{Fe}=168 \mathrm{mg} \mathrm{dm}^{-3}$; Mn: $1.9 \mathrm{mg} \mathrm{dm}^{-3} ; \mathrm{Zn}: 2.9 \mathrm{mg} \mathrm{dm}^{-3}$; and 801, 19 and $180 \mathrm{~g} \mathrm{~kg}^{-1}$ of sand, silt and clay, respectively (Embrapa, 2011).

The soil of the experimental area was prepared by plowing and harrowing after liming, performed 90 days before transplanting of seedlings, aiming to raise the base saturation $(\mathrm{V})$ to $80 \%$. The liming, fertilization of planting and covering were done manually, according to the crop requirements (Cravo et al., 2007). The amounts of fertilizers applied were: $90 \mathrm{~kg} \mathrm{~N} \mathrm{ha}^{-1}$ using urea, $200 \mathrm{~kg} \mathrm{P}_{2} \mathrm{O}_{5}$ ha $^{-1}$ using single superphosphate, and $90 \mathrm{~kg} \mathrm{~K}_{2} \mathrm{O}$ ha $^{-1}$ using potassium chloride. All phosphorus was applied in the furrow, and $\mathrm{N}$ and $\mathrm{K}$ were applied in coverage. The applications occurred at 10, 20 and 30 days after transplanting (DAT). Boron (with borax) was applied foliarly, in coverage, in two applications, in the ratio of $1 \mathrm{~g}$ : 10 liters of water. To prepare the furrows, $40 \mathrm{t} \mathrm{ha}^{-1}$ goat manure was used in the organic fertilization.

Pest and disease control was carried out once a week. The systemic insecticide Actara (TIAMETOXAM) and the contact insecticide Decis (DELTAMETRINA) were used for the control of whitefly (Bemisia tabaci) and aphid (Brevicoryne brassicae), with product rotation. We used a manual costal sprayer for the applications.

Water was supplied with a drip irrigation system, being distributed to the plots through a dripping hose with $16 \mathrm{~mm}$ in diameter, with drippers spaced $20 \mathrm{~cm}$ apart, and with a water flow rate of $2 \mathrm{~L} \mathrm{~h}^{-1}$ per emitter, at a pressure of $58838.28 \mathrm{~Pa} \mathrm{~Pa}$. Daily irrigations were carried out to reach the soil tension at field capacity (10 kPa), being monitored by a tensiometer installed at $20 \mathrm{~cm}$ depth in the soil of the area.

The experimental design was randomized blocks, with five treatments and three replications. The treatments consisted of rates of $0,90,180,270$ and $360 \mathrm{~kg} \mathrm{~N} \mathrm{ha}^{-1}$, using urea as source, applied in top dressing.

The cabbage variety used in this study was "oxheart". Seedlings were produced with organic compound in 200-cell polypropylene trays. The experimental plots had $3.20 \mathrm{~m}$ in width and $2.50 \mathrm{~m}$ in length. Four planting rows, spaced $0.8 \mathrm{~m}$ apart and $0.50 \mathrm{~m}$ between plants, were used, totaling 20 plants per plot, where only the six central plants were considered useful. Seedlings were transplanted when they had 4-5 full leaves (08/12/2015), at 42 days after sowing.

Harvest occurred in three stages: at 87, 93 and 100 DAT, the last one culminating with the closing of the experiment, on November 20, 2015, totaling a cycle of 142 days from sowing. The harvest time was determined when the plants had a compact head and the cover leaves were beginning to curl back slightly, exposing the inner, clearer leaves.

To evaluate the effect of nitrogen fertilization, the following parameters were analyzed: biometry (plant height - $\mathrm{PH}$, canopy diameter - $\mathrm{CD}$ and number of leaves - NL); fresh and dry mass of the head (HFM, HDM); longitudinal diameter (LD); transverse diameter (TD); and commercial yield (CY), being considered commercial all the heads that were compact at harvest. Biometry was done one day before harvest, when the plants showed maximum development. $\mathrm{PH}$ was determined from the lap of plants, close to the ground, to the maximum average height of the apical leaves; $\mathrm{NL}$ represents the number of leaves of plants; CD consisted of the average of two perpendicular diameters, measuring the distance between the ends of the plant. Measurements were performed using a metal tape measure.

The other variables were evaluated as they were collected; in each plot, six uniform and representative plants of the treatment were collected. These plants were weighed, and all leaves were removed to obtain the head fresh mass (HFM). HDM was determined using 6 plants per plot, which were weighed and placed in paper bags, being subsequently kept in a forced air oven at $65^{\circ} \mathrm{C}$ until reaching constant weight. The dry mass was weighed with a $0.001 \mathrm{~g}$-precision scale, obtaining the average dry mass. A precision scale and an oven were used to evaluate HFM and HDM, and a digital caliper to evaluate TD and LD. CY was expressed in $\mathrm{kg} \mathrm{ha}^{-1}$, being estimated through the population of plants in one hectare and the HFM per plant.

Data were submitted to the "F" test, and when the variation was significant, regression analysis was performed at $1 \%$ and $5 \%$ significance level. 


\section{Results and discussion}

The head fresh mass (HFM) production responded markedly to the increase of nitrogen rates, presenting a quadratic effect $(p<0.05)$ (Figure
1A). Such a finding demonstrates that nitrogen is important for the maximum increase in head fresh matter, resulting in increased productivity. The estimated maximum value of HFM $(0.60 \mathrm{~kg})$ was obtained with $249.5 \mathrm{~kg} \mathrm{~N}^{-1}$ (Figure $1 \mathrm{~A}$ ).
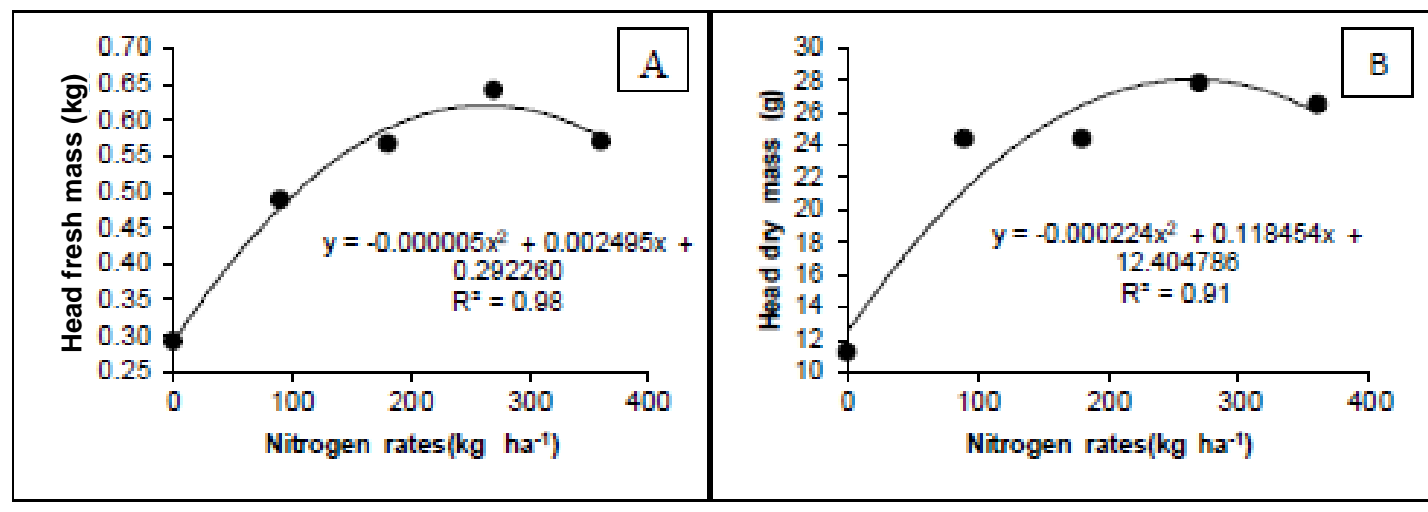

Figure 1 - Head fresh mass $(A)$ and head dry mass $(B)$ as a function of nitrogen rates.

The value obtained was lower than that observed by Moreira et al. (2011), in Minas Gerais, from July to October, in the Shutoku hybrid $\left(1.133 \mathrm{~kg}\right.$ estimated with the dose of $\left.278 \mathrm{~kg} \mathrm{~N} \mathrm{ha}^{-1}\right)$. Therefore, the intensity of the response to the applied $\mathrm{N}$ may depend on factors such as time of year (Santos et al., 2012) and cultivar (Aquino et al., 2005a). The high temperatures of the North region can also justify this difference, since high temperatures have been a limiting factor for the cultivation of this vegetable in several regions of Brazil, affecting the development and quality of the heads, and increasing problems with pests and diseases.

The estimated optimum value of HDM (28.02 g) was obtained with $249.5 \mathrm{~kg} \mathrm{~N}^{-1}$ (Figure 1B). Increased cabbage head fresh matter with increasing nitrogen rates is also confirmed by Aquino et al. (2005a). In addition, Haque et al. (2006) and Din et al. (2007) found that $\mathrm{N}$ fertilization significantly increases head yield under field conditions.

The estimated maximum commercial yield (CY; $16883.81 \mathrm{~kg} \mathrm{ha}^{-1}$ ) was obtained with the maximum rate of $270.27 \mathrm{~kg} \mathrm{~N}^{-1}$ (Figure $2 \mathrm{~A}$ ).

Plant height, number of leaves and canopy diameter increased quadratically $(p<0.01)$ with increasing nitrogen rates. With the nitrogen dose that maximized the HFM $\left(249.5 \mathrm{~kg} \mathrm{~N} \mathrm{ha}^{-1}\right)$, the values of $\mathrm{PH}$; $\mathrm{NL}$ and $\mathrm{CD}$ were $25 \mathrm{~cm} ; 17 \mathrm{~cm}$ and $42.08 \mathrm{~cm}$, respectively (Figures $2 \mathrm{~B}, 2 \mathrm{C}$ and $2 \mathrm{D}$ ). The increase in stem length and NL with increased nitrogen rates is due to the growth-promoting effect of nitrogen (Cardoso \& Hiraki, 2001; Ferreira et al., 2002; Cecílio Filho et al., 2016). Ekbladh et al. (2007) and Cecílio Filho et al. (2013) found a relationship of proportionality between leaf canopy area and nitrogen, showing a direct relationship between leaf canopy area expansion and $\mathrm{N}$ uptake.

This expansion of the plant stem and canopy with nitrogen doses can be justified by the direct relationship between plant development and nitrogen requirement, considering that the aforementioned nutrient is present in the chlorophyll structure, which is the pigment responsible for photosynthesis. Notwithstanding, very high doses of nitrogen may lead to excessive vegetative growth, which may hinder yield development.

With the optimum nitrogen rate for HFM production (249.5 $\mathrm{kg} \mathrm{N} \mathrm{ha}^{-1}$ ), the optimum estimated values of LD and TD were $127 \mathrm{~mm}$ and $100 \mathrm{~mm}$, respectively (Figures $3 \mathrm{~A}$ and $3 \mathrm{~B}$ ). These values are close to those verified by Moreira et al. (2011), of $16.9 \mathrm{~cm}$ (TD) and $12.7 \mathrm{~cm}$ (LD), obtained with the rate that maximized yield $\left(277.8 \mathrm{~kg} \mathrm{~N}^{-1}\right)$. Increased head volume with increasing rates of $\mathrm{N}$ was also observed by Aquino et al. (2005b).

The results show the importance of nitrogen in plant growth. Increased rates of this nutrient stimulated cabbage growth in the edaphoclimatic conditions of the region, resulting in a higher head fresh mass production and higher productivity. However, the data obtained are not sufficient to recommend nitrogen fertilization. New studies are needed to consolidate the crop in the region.

\section{Conclusions}

The $\mathrm{N}$ rate to obtain the maximum production of cabbage heads is $249.5 \mathrm{~kg} \mathrm{~N} \mathrm{ha}^{-1}$, and the $\mathrm{N}$ rate to obtain the maximum commercial yield is $270.27 \mathrm{~kg} \mathrm{~N} \mathrm{ha}^{-1}$. 


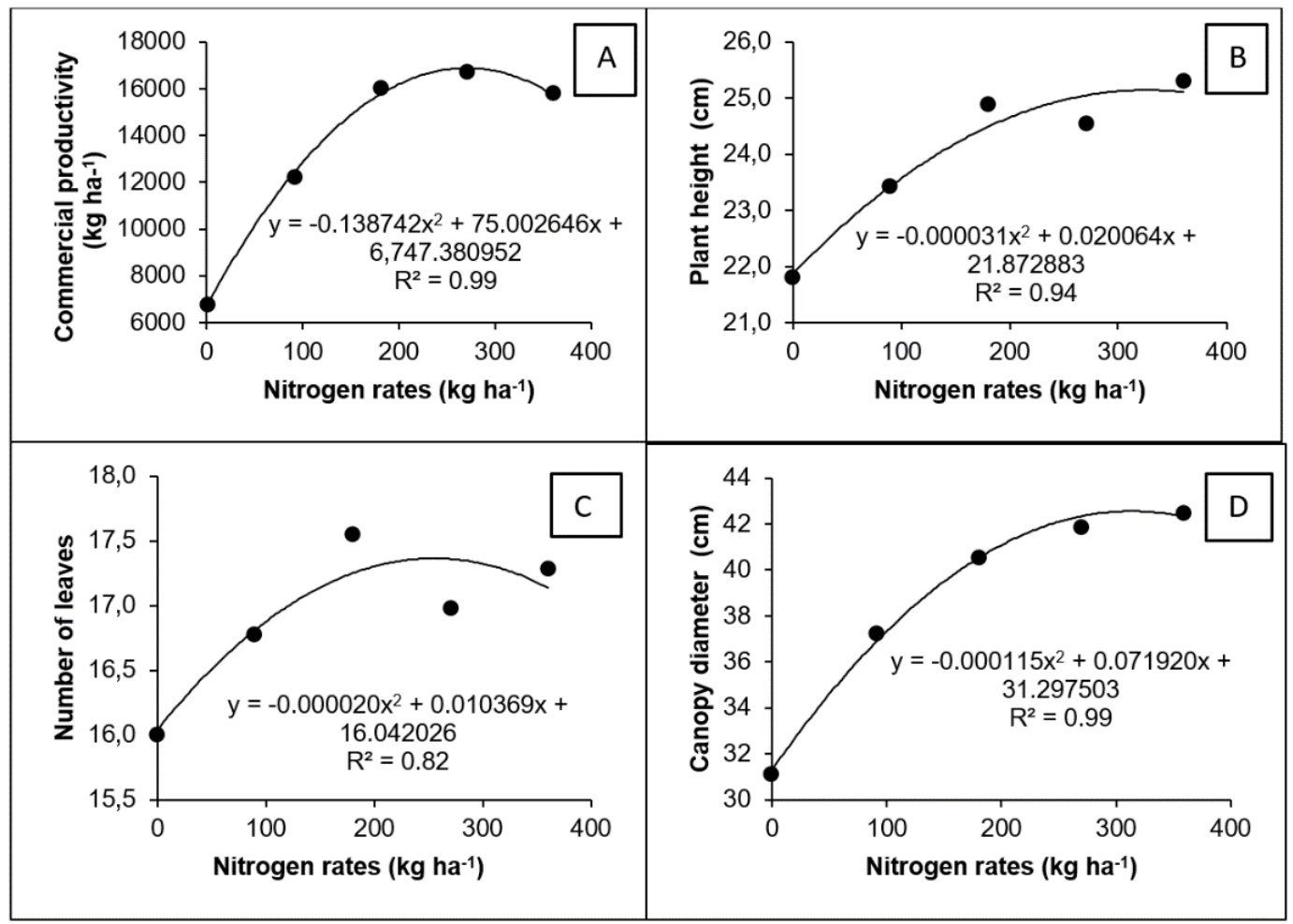

Figura 2 - Commercial productivity (A), plant height (B), number of leaves (C); and canopy diameter (D) as a function of the nitrogen rates.

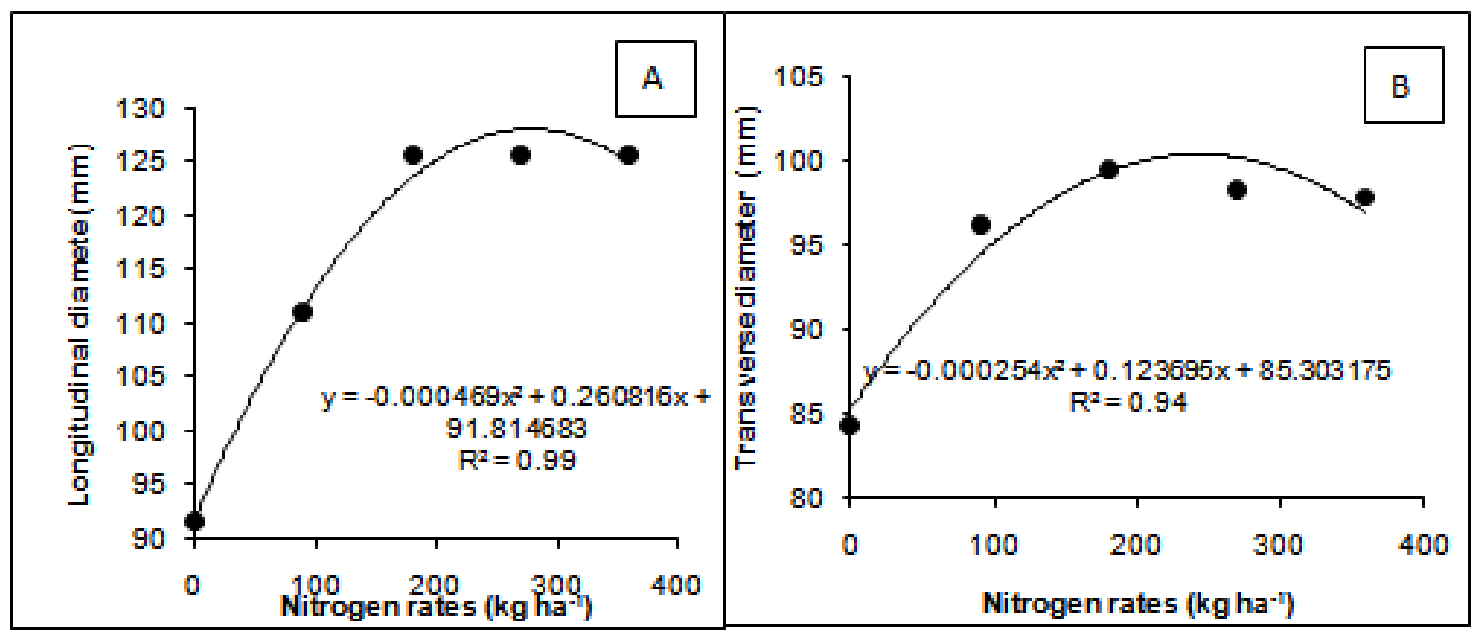

Figura 3 - Longitudinal diameter (A) and Transverse diameter $(B)$ as a function of the nitrogen rates.

\section{Acknowledgements}

To the National Council for Scientific and Technological Development (CNPq) for granting financial support to the research.

\section{References}

Aquino LA, Puiatti M, Pereira PRG, Pereira FHF, Castro MRS, Ladeira IR (2005a) Características produtivas do repolho em função de espaçamentos e doses de nitrogênio. Horticultura Brasileira 23 (2): 266-270.
Aquino LA, Puiatti M, Pereira PRG, Pereira FHF, Ladeira IR, Castro MRS (2005b) Efeito de espaçamentos e doses de nitrogênio sobre as características qualitativas da produção do repolho. Horticultura Brasileira 23:100-104.

Aquino LA, Puiatti M, Lélis MM, Pereira PRG, Pereira FHF (2009) Produção de biomassa, teor e exportação de macronutrientes em plantas de repolho em função de doses de nitrogênio e de espaçamentos. Ciência e Agrotecnologia 33(5):1295-1300. 
Cardoso All, Hiraki H (2001) Avaliação de doses e épocas de aplicação de nitrato de cálcio em cobertura na cultura do rabanete. Horticultura Brasileira 19(3):328-331.

Cecílio Filho AB, Silva GS, Cortez JWM (2013) Phosphorus fertilization of 'Fuyutoyo' cabbages in phosphorus-rich Eutrustox soil. Chilean Journal of Agricultural Research 73:288-292. doi:10.4067/S0718-58392013000300012 .

Cecílio Filho AB, Cavarianni RL, Nowaki RHD (2016) Accumulation of macronutrients in cV. 'Astrus' cabbage as influenced by nitrogen dose and plant population. Ciencia e Investigación Agraria, 43(2):305-315. doi: 10.4067/S0718-16202016000200013.

Cravo MS, Viégas IJM, Brasil EC (2007) Recomendações de adubação e calagem para o Estado do Pará. Belém, PA: Embrapa Amazônia Oriental. 189-190.

Din M, Qasim M, Alam M (2007) Effect of different levels of N, P and $\mathrm{K}$ on the growth and yield of cabbage. Journal of Agriculture Research 45(2):171-176.

Embrapa (2011) Manual de métodos de análises de solo. 2.ed. Centro nacional de pesquisa de solos, Rio de Janeiro: Embrapa. 230p.

Embrapa (2013) Centro Nacional de Pesquisa de Solos. Sistema Brasileiro de Classificação de Solos, 3.ed. Rio de Janeiro: Embrapa. 353p.

Ekbladh G, Witter E, Ericsson T (2007) Ontogenetic decline in the nitrogen concentration of field grown white cabbage - Relation to growth components. Scientia Horticulturae 112:149-155.
Ferreira WR, Ranal MA, Filgueira FAR (2002) Fertilizantes e espaçamento entre plantas na produtividade da couve-da-malásia. Horticultura Brasileira 20:635-640 .

Haque KMF, Jahangir AA, Haque ME, Ondal RK, Jahan MAA, Sarker MAM (2006) Yield and nutritional quality of cabbages as affected by nitrogen and phosphorus fertilization. Bangladesh Journal of Scientific and Industrial Research 41(1):41-46.

Kano $Y$, Nakagawa $H$, Sekine $M$, Goto $H$, Sugiura $A$ (2007) Effect of nitrogen fertilizer on cell size and sugar accumulation in the leaves of cabbage (Brassica oleracea L.). HortScience 42(6):1490-1492.

May A, Tivelli SW, Vargas PF, Samra AG, Sacconi LV, Pinheiro MQ (2007). A cultura da couve-flor. Boletim Técnico, Campinas: IAC, n. 200, p. 43.

Moreira MA, Vidigal SM, Santos MR (2011) Crescimento e produção de repolho em função de doses de nitrogênio. Horticultura Brasileira 29:117-121.

Santos MM, Galvão JCC, Silva IR, Miranda GV, Finger FL (2012). Épocas de aplicação de nitrogênio em cobertura na cultura do milho em plantio direto, e alocação do nitrogênio $\left({ }^{15} n\right)$ na planta. Revista Brasileira de Ciencia do Solo 34:1185-1194.

Torres JLR, Fabian AJ, Pocay VG (2003). Níveis de adubação nitrogenada nas características morfológicas e produtivas do jiló. Horticultura Brasileira 21(2): 167-170. 